\title{
Future waterscapes of the Swiss Jura: using speculative photo-response fabulation techniques with farmers
}

\author{
Rémi Willemin $^{1,2}$ and Norman Backhaus ${ }^{1,2}$ \\ ${ }^{1}$ Department of Geography, University of Zurich, Zurich, 8057, Switzerland \\ ${ }^{2}$ URPP Global Change and Biodiversity, University of Zurich, Zurich, 8057, Switzerland \\ Correspondence: Rémi Willemin (remi.willemin@geo.uzh.ch)
}

Received: 28 March 2020 - Revised: 10 February 2021 - Accepted: 25 February 2021 - Published: 22 April 2021

\begin{abstract}
In response to global change and biodiversity loss caused, inter alia, by agricultural practices, our speculative photo-response fabulation project with farmers and beekeepers in the Jura region co-develops perceptions of the future of Switzerland's waterscapes. Research participants imagine and narrate the most probable and most desired futures of waterscapes in 2222. The technique of speculative photo-response fabulation uses photographs to elicit participants' concerns over probable ecosystem degradation and drought in the Jura contrasted with their desired futures of sustainability. In their responses, participants envision actions that support systemic changes in opposition to a frontier spirit of economic profit that causes biodiversity loss.
\end{abstract}

\section{Introduction}

"Take a comfortable position and relax. Imagine that you are travelling into outer space. On your way back, we are in the year 2222. You see two planet Earths: one is the probable future of the Earth if things continue the way they are now; the other, its desired future, is the one you aspire to. Now land on the probable future Earth and go to the place where you took a photograph of a landscape that best depicts your relationship to water. Pay attention to details: what nature surrounds you? What activities are taking place there? What noises are around you? Finally, take a mental picture at the same spot and angle as your photograph. What do you see?" (Guidelines for speculative photo-response fabulation, own shortened version)

These guidelines were given to seven farmers and/or beekeepers (hereafter referred to as "farmers") in the Swiss Jura who participated in our research about perceptions and imaginations of future waterscapes. This task introduced a participatory visual speculative research technique that enables the farmers to use pictures, metaphors and associations to contrast two types of envisioned futures: the most probable and the most desired. For this purpose, we combined two techniques: photo-response (Alam et al., 2018) and speculative fabulation (Wilkie et al., 2017). Both aim to cultivate what Haraway (2016) named "multispecies response-ability" as an ability to be accountable for an action or idea to those affected by this action or idea and to respond accordingly.

In line with a recent turn in nature-society scholarship towards experimentation and invention "to engender new forms of knowing and dwelling in and with human and nonhuman others" (Braun, 2015:241) and with the subfield of future anthropology (Pink and Salazar, 2017), we discuss how research participants imagine, tell and transform the futurity of waterscapes. Futurity is here understood as (culturally constructed semiotic) imaginaries and (individually constructing embodied) imaginations of both probable and desired futures. Imaginaries can be understood as "that common understanding that makes possible common practices and a widely shared sense of legitimacy" (Wagner, 2012:620 quoting Taylor, 2004:23). Futurity is revealed to be shaped by material and mental images and their related emotions.

Inspired by an approach towards an interim politics of resourcefulness, we intend to co-develop "visions for just socionatural futures ... generated in conversation with historically marginalized communities" (Derickson and MacKinnon, 2015:304), in our case, farmers whose practices are af- 
fected by global change (water stress, loss of soil fertility, increases in or new invasive species, etc.) and biodiversity loss. Based on Haraway's consideration (1988:585) that "vision is always a question of the power to see and perhaps of the violence implicit in our visualizing practices", our participatory visual speculative research implicitly questions whose visions are legitimised or delegitimised by which visualising practices.

During our research, one farmer described his vision of a desired future with a system that would create economic incentives to follow environmentally sustainable practices using the term "realism". According to Lefebvre (1957), we interpret this farmer's vision of future waterscapes as conscious of the dialectic of possible-impossible ${ }^{1}$. Naming a desired future realism is a way to claim (back) legitimacy of an emic vision on alternative futures even if the implementation of possible vision seems improbable in the current economic system. Participants risk performing speculative photo-response fabulation as they feel "bound by a situation, bound to respond to virtualities made perceptible only by the way in which one is bound" (Debaise and Stengers, 2017:19).

We first introduce influential theories on probable and desired futures before detailing our methodology. Subsequently, we present the visions and emotions of probable and desired futures and interpret metaphorical associations made about distant waterscapes in space and time. We draw upon criticism of the "frontier spirit" (Adam and Groves, 2007) to discuss concerns over biodiversity issues. We consider how futurity is built through visual metaphors and influenced by visuality, other senses and embodied emotions. We also reflect on the performativity of emotions when participants voice visions of desired waterscapes in opposition to probable conflicts and waterscape degradation. We conclude by recapping potentially competing or co-evolving desired futures and their pathways and open up the technique of speculative photo-response fabulation to other settings.

\section{Theorising probable and desired futures}

Scientific probabilistic projections have acquired a dominant legitimacy in telling, taming and transforming probable futures (Adam and Groves, 2007). Probable futures "provide the power to be right" by projecting past trends into the future (Debaise and Stengers, 2017:19). However, probable projections, for instance in discourses on the Anthropocene, produce fears that may reduce or block systemic changes (Cook and Balayannis, 2015). Moreover, techno-scientific appara-

\footnotetext{
${ }^{1}$ We relate the dialectic of possible-impossible (Lefebvre, 1957) to the (im)possible visions mentioned in the title of the 2019 Deutscher Kongress für Geographie session which instigated this article: “(Un)mögliche Zukunftsvisionen - Qualitativmethodische Zugänge zu Imaginationspraktiken und Raum-Bildern von Zukunft".
}

tus guiding our responses to climate change disempowers most people (Nightingale et al., 2020). This may result in a positivist "comic faith in technofixes" or in bitter and cynical game-over attitudes (Haraway, 2016).

In contrast to probable futures, desired futures come from "the capacity to aspire" (Appadurai, 2013:188-93), understood as a navigational meta-capacity depending on the opportunities to have various possible futures and to test the one aspired to. The most desired future provides an ethical collective horizon giving meaning, substance and sustainability to capabilities of the aspirers. According to Lefebvre (1957), some desired futures can be revolutionarily romantic when the aspirer is conscious of the dialectic of possible-impossible: the vision seems technically possible but its implementation improbable due to the alienation to the labour division as well as to social, ethical, aesthetical and spiritual orders that prevail. Furthermore, possible (desired) futures are opposed to the real (including the past trends that probable futures follow) and are integrally (and performatively) part of its movement.

In this sense, Debaise and Stengers (2017:18) call for "a thinking that commits to a possible, by means of resisting the probable" through speculative fabulation. Speculative fabulation is, according to Åsberg (2015), a performative process of making worlds, a form of world-making or "worlding" (according to Haraway, 2016), i.e. a systematic theorisation or a story in which words perform possible and contingent worlds (Åsberg, 2015). Like a prism, speculative fabulation diffracts the probable into many possibles. Thus, speculative research faces an interpretative task of understanding what converges among many possibles, among a "plurality of modes of importance" (Debaise and Stengers, 2017:17). Speculative pragmatism offers a way to narrow down possibles by calling on our research participants' desired futures as desires are reflexive assemblages for feeling and thinking about what they are really responsible for (Debaise and Stengers, 2017; Stengers, 2018). Voicing desired futures - in speculative fabulation - is thus an act of resistance and an imperative response to a situation in which the speculator feels bound. Speculation differs from utopia or dystopia as it arises from an experienced (observed) reality with the intention to safeguard as a scout (Pihet et al., 2017:70) or to act as "the figure of the diplomat" giving peace a chance against the state of affairs that would logically lead to war (Stengers, 2018:85).

\section{Methodology - speculative photo-response fabulation}

Our project took place from March to September 2019 in the Swiss Jura mountains (cantons of Neuchâtel and Jura), a region sensitive to droughts and pollutants that infiltrate the karst groundwater (Hoffmann et al., 2014). Among various sources of water contamination, agricultural inputs leaking 
into watercourses and groundwater are known to threaten the survival of an endangered fish species, the apron (Zingel asper), in the river Doubs, inducing new regulations on farming practices (Hefti et al., 2015). To better understand waterscape degradation through situated knowledge (Haraway, 1988, 2016), participation in the project was open to farmers in the Jura to draw upon their first-hand perspectives as practitioners. The first author received contact information through an agritourism project and called potential participants to present the research project through a university programme on global change and biodiversity. Seven farmers met him twice: first to discuss past and present perceptions of waterscapes based on participants' photography and then to imagine the futures of waterscapes in order to co-develop and analyse how participants build discursively the futurity of waterscapes.

In order to perform speculative photo-response fabulation, participants were requested to each take three landscape photos that best depict their relationships to water before the first meeting. At the meeting, they interpreted their photographs in terms of relationships to water, potential detrimental products in water ecosystems and social activities that could occur in the photographed waterscape. Their interpretation formed the bases of semi-structured interviews that lasted about $2 \mathrm{~h}$ per participant or couple of participants. The meeting was based upon developing participants' own problematisation of waterscapes: their specific ground or problem for creating - in the second meeting - a situated speculative fabulation (Wilkie et al., 2017:62). In the second meeting which lasted about 90 min per participant, we used a storytelling technique. Each participant chose one of their waterscape pictures and used it as a "vantage point" (Alam et al., 2018; Haraway, 1988) from where they jumped into a space-time imaginative journey of situated speculation (Wilkie et al., 2017:58-59). After listening to the guidelines summarised at the introduction of this article, the participants narrated their imaginative journey into probable and desired futures in 2222, a period covering approximately eight generations. They were asked open questions such as, "how have the relationships changed between water, human activities, and products that can affect water quality?" Participants also described their emotions when imagining probable and desired futures and which actions will have been taken to make such desired futures come true. In our discussion, we followed the recommendations of Fabrizio Terranova (Pihet et al., 2017:72) to "avoid anthropocentric stories" (by focusing on more-than-human non-hierarchical relationships in waterscapes), to support the "struggle of possibles versus probables" (by imagining probable and desired futures), and to build "propositional forces, ... beyond criticism and condemnation" (by (fore)seeing what will have been done to realise the desired futures).

The talks were recorded, transcribed and subsequently analysed in association with the images. Based on research participants' narratives, we identified visual metaphors and associations between places distant in space and time and deducted regional discursive formations of futurity. We followed a non-representational visual analysis approach (Schlottmann and Miggelbrink, 2015; Thrift, 2008) combining the materiality of images with the corporeality (senses and embodied emotions) of the photographers and their assignment of meanings. Speculative photo-response fabulation reflects futures as the things we care for: the futures are perceived from a present position, revealing a world within which nothing "is encountered without it 'mattering' to us" (Adam and Groves, 2007:126-128, 193). The technique helped elicit what mattered to the participants when they produced images as photographers and then interpreted them in over 200 years' time. Participants' narratives built mental images of futures based on what they care about in a waterscape. They revealed unperceivable signs in the photography and, sometimes, things participants said they did not think of when taking the picture. Hence, the technique uncovers a range of connotations: conceivable, symbolic or ideological meanings of photographs.

\section{Summarising speculative photo-response fabulation}

\subsection{Probable futures created in association with dry, southern Europe}

Many participants associate probable futures of the Jura with southern regions at present. For instance, Rose (all names are pseudonyms) considers that, in 2222, plants such as olive trees populated with goldfinches will grow in the landscape depicted in Fig. 1. The pond will dry up, and, in adapting to water shortage, people will mix crops and live in yurts, tending to sheep and goats as nomadic pastoralists. Moreover, when describing their waterscapes in 2222, participants often describe elements outside the frame of their photographs to explain how their picture-framed waterscape will change and will be changed through global processes.

Gabriel describes the bottom of the valley for his photo (Fig. 2) that he thinks will remain productive, 5 times more than the mountain base and 10 times more than the higher grounds. "Humans will have to make food. As long as this stream flows, hope lasts. And I think it will still flow in 2 centuries." Gabriel did not think of that when he took the picture, but he sees very dry mountains on the slope exposed to the sun, as in the south of Italy or France. His voice sounds sad when addressing probable drought risks. In his description of a probable future, Gabriel expresses concerns over severe "social misery" and hunger on a global level. "We are not going to be able to continue to make people [here] envy living on top of the rest of the world.... In 2 centuries there will still be a fight for resources ... over political and religious things often far removed from the problems of misery."

Léo describes a future waterscape that will look like Mediterranean areas such as the Côte d'Azur, with a bushier 


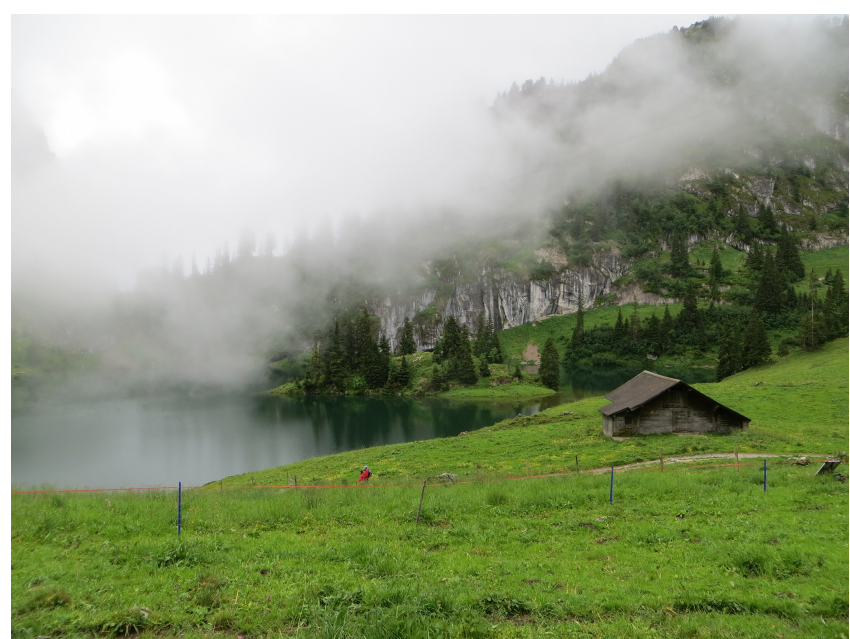

Figure 1. (Rose) A future dryland with yurts and nomadic pastoralists. (The figure captions summarise waterscapes' probable futures.) This figure is distributed under the Creative Commons licence Attribution-NonCommercial-NoDerivs (CC BY-NC-ND).

forest with copses. On the north side (see Fig. 3), native trees will remain because of the advantage - nowadays a disadvantage - of having 2 months without direct sunshine (from 21 November to 21 January), when evapotranspiration is almost non-existent. Thus, the soil will regenerate quickly and stay fertile. Moreover, in the case of drought in winter, the retention capacity of the soil will still remain intact. As a probable future on the global scale, Léo assumes that climate change will provoke drought, thirst, famine and flooding and that "without a revolution, in 50 years, only half of the population will survive because of disasters such as epidemics, civil wars over food and water, or warlike bullshit, because extremes are fed by conflicts." Merging desired and probable futures by claiming futures alternative to agroindustry, Léo hopes that 50 years from now we will have decided to use chemicals only as a last resort; thus, the biodiversity in this waterscape will slightly improve, and the wetlands will survive due to intense rainfall.

Jules and Louise (a couple) consider that almost nothing in Fig. 4 will remain in 2222. By then, the Doubs will be a small creek during the winter and dry from April to October. Since they live in (karstic) mountains, Louise wonders where people will get their water. According to her, the tipping point (point de rupture) is not that far away. Jules assumes that "we're going to start moving water by truck", as is currently done in France in regions that suffer from drought. They argue that people have the stubborn determination today to want nature to adapt to human activities at all costs, and "as long as we go in that wrong direction, we are accelerating the wheel of destruction [i.e. by trucking in water and polluting]". Moreover, they assert that economic development is destroying the course of normal animal, human and plant life, where cycles are self-perpetuating. Jules fi-

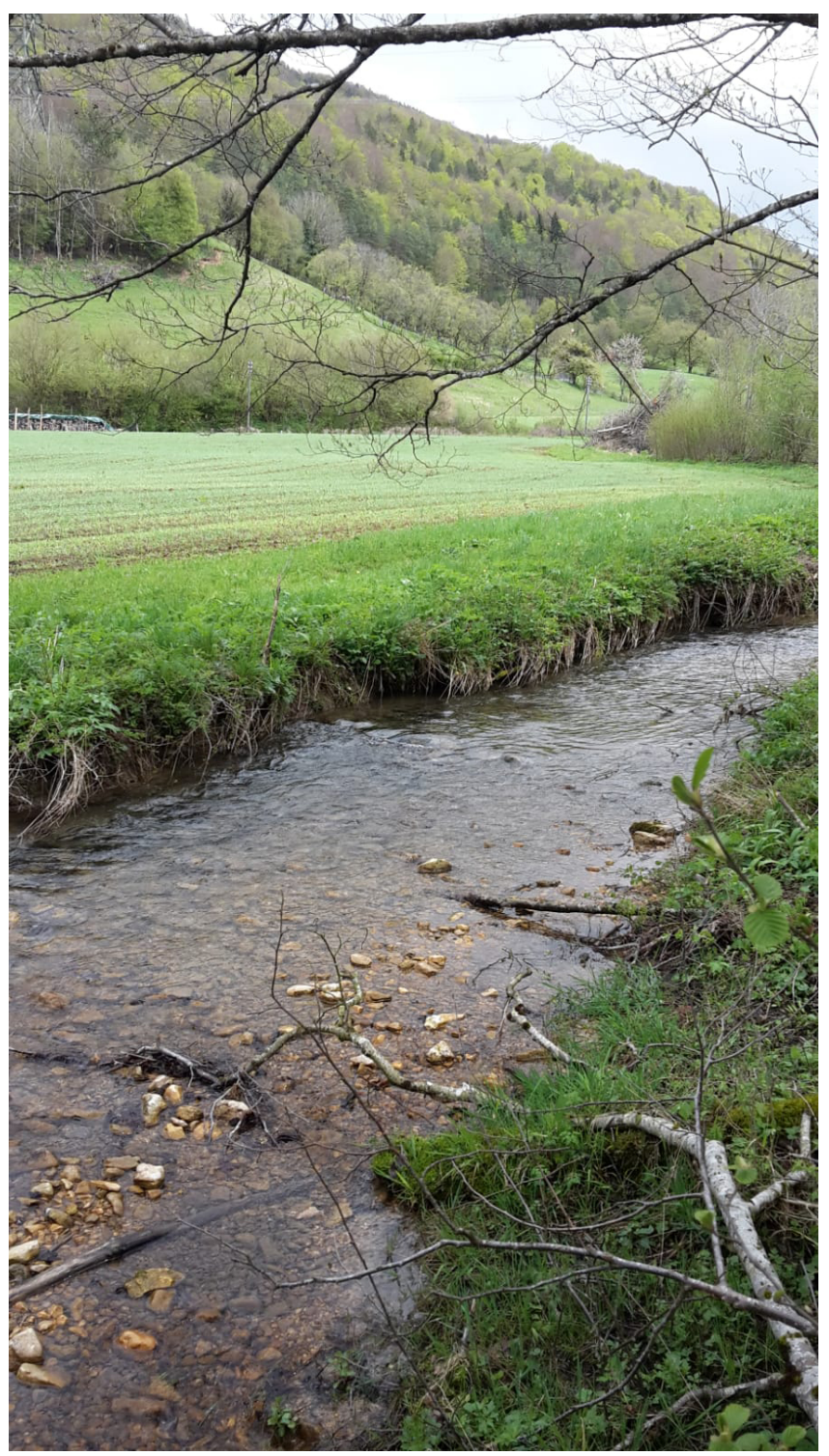

Figure 2. (Gabriel) A future productive valley and dry mountains like the south of France. This figure is distributed under the Creative Commons licence Attribution-NonCommercial-NoDerivs (CC BYNC-ND).

nally describes the future waterscape as a "Chernobyl": "polluted areas with mutant animals or insects where people will no longer be able to live, nor have the right to grow vegetables, nor dare to drink water because of the possibilities of becoming intoxicated".

\subsection{Negative emotions surrounding probable futures}

Next, research participants describe how they feel emotionally imagining the probable futures and describe what these emotions motivate them to do. Gabriel considers that "it would be such a painful waste if it came to a war". It would 


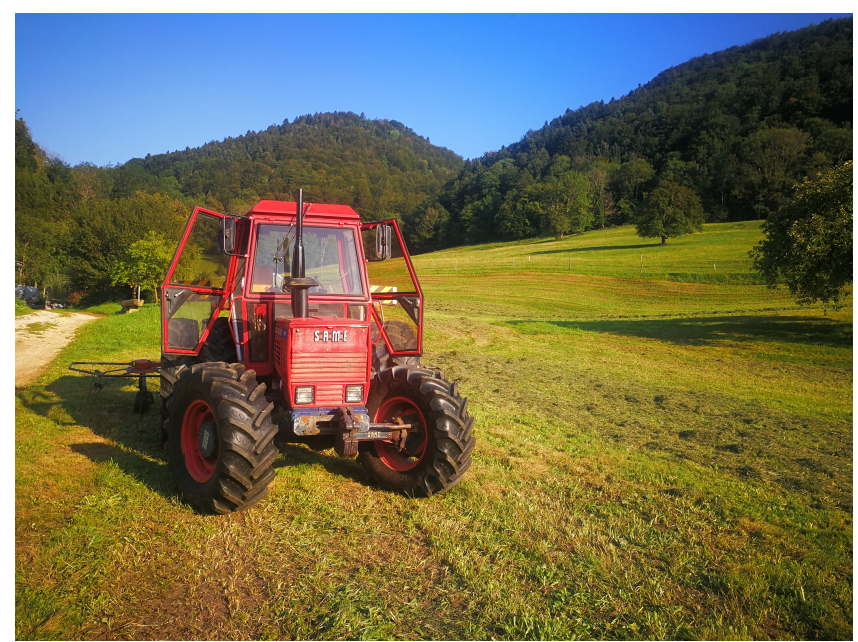

Figure 3. (Léo) Future farm land as the current Côte d'Azur with wetlands. This figure is distributed under the Creative Commons licence Attribution-NonCommercial-NoDerivs (CC BY-NC-ND).

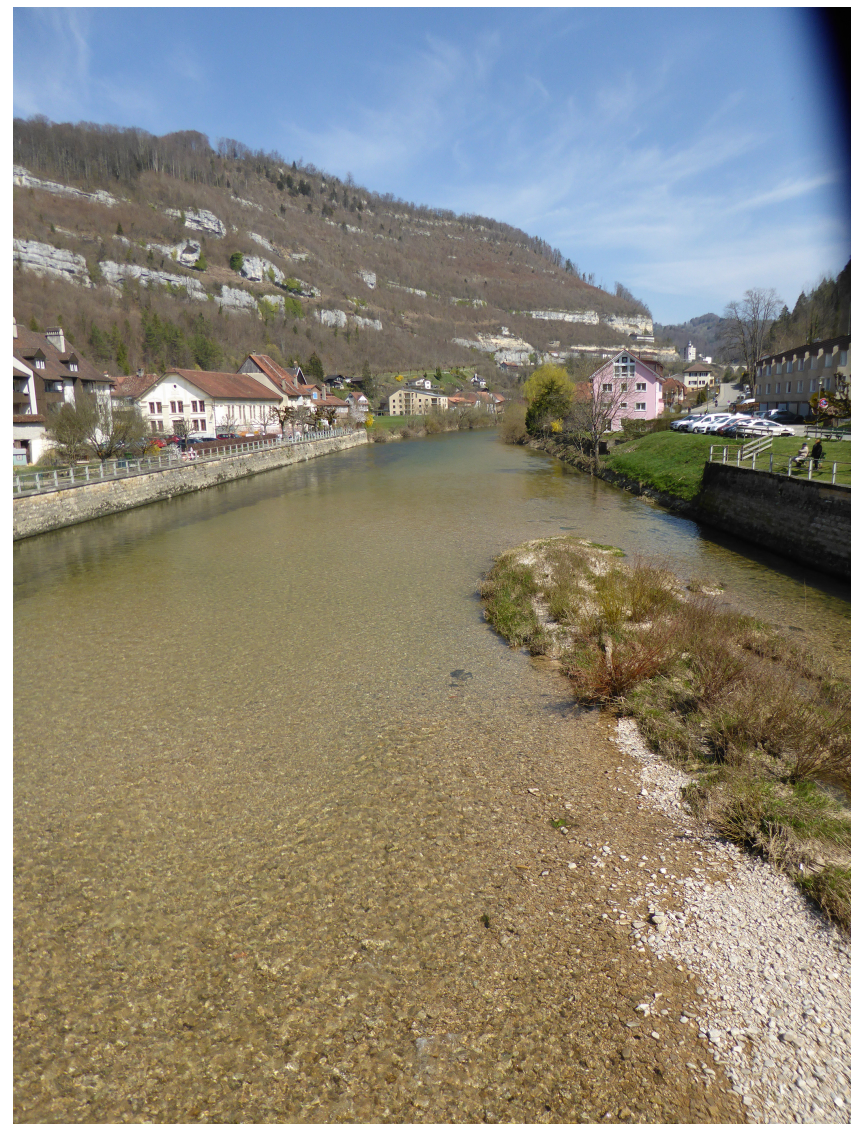

Figure 4. (Jules and Louise) The future Doubs like a little creek or like Chernobyl. This figure is distributed under the Creative Commons licence Attribution-NonCommercial-NoDerivs (CC BY-NCND).

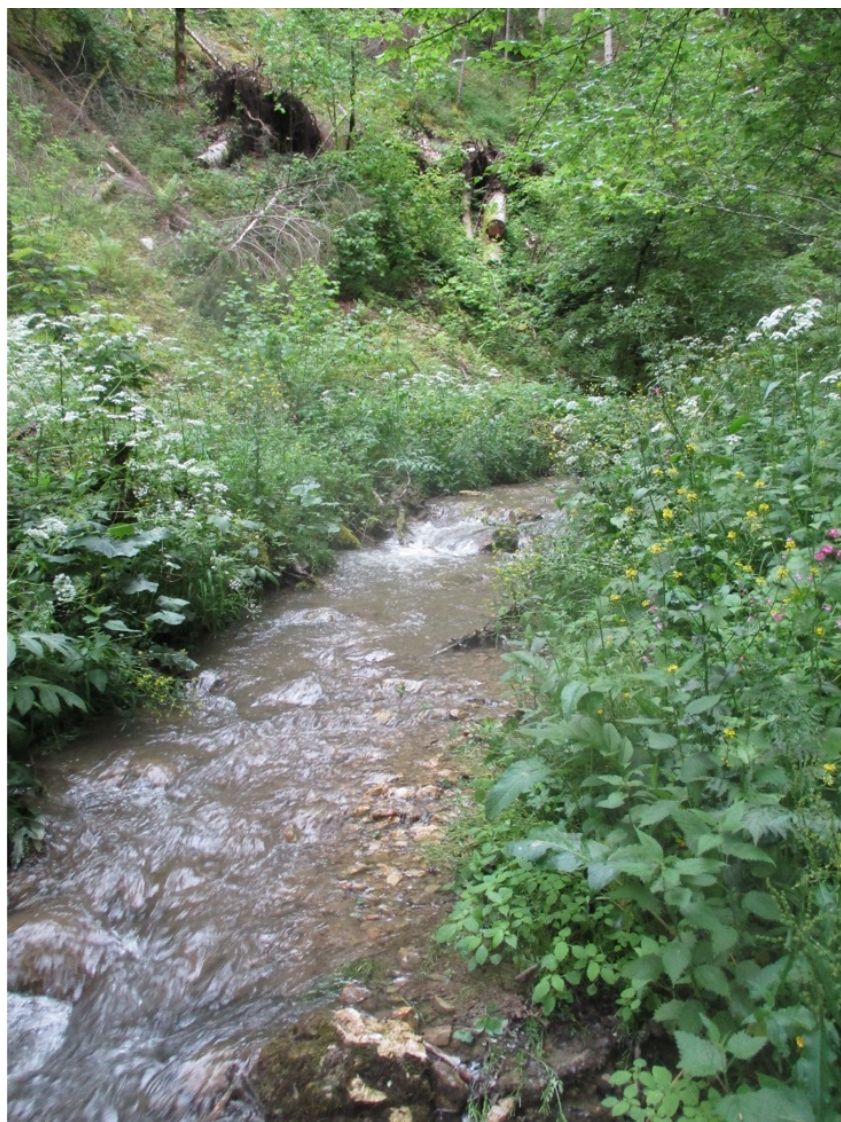

Figure 5. (Juliette) A future desert carved as a canyon. This figure is distributed under the Creative Commons licence AttributionNonCommercial-NoDerivs (CC BY-NC-ND).

hurt him to know that humans had "broken everything". His strongest emotion in the probable future is a "certain sadness in not finding a solution, because we would have solutions". The sadness motivates him first to discuss "being a sustainable farmer ... to stop this, take responsibility for ourselves here, for our food, as much as possible ... not exploit the rest of the world, and then give people a chance to stay at home there". Conscious of the possible-impossible, he suggests that "we could produce things on fields where it is not probable. [Instead, currently] we import products from the other side of the world".

Similarly, Juliette says: "the probable is sad, because from what we are seeing, I don't think we will be able to act on the changes that are on the way in time to stop the disaster. The landscape I saw [Fig. 5] was bare of any green; [it was a] desert: no more water, no more freshness and no more of this little noise [from the river]". She states that we do not know how far away we are from significant changes that will permanently disrupt ecosystem mechanisms. "When it becomes unpredictable, it becomes very difficult, at least for humans, to live on this planet." Concerned with the state of 


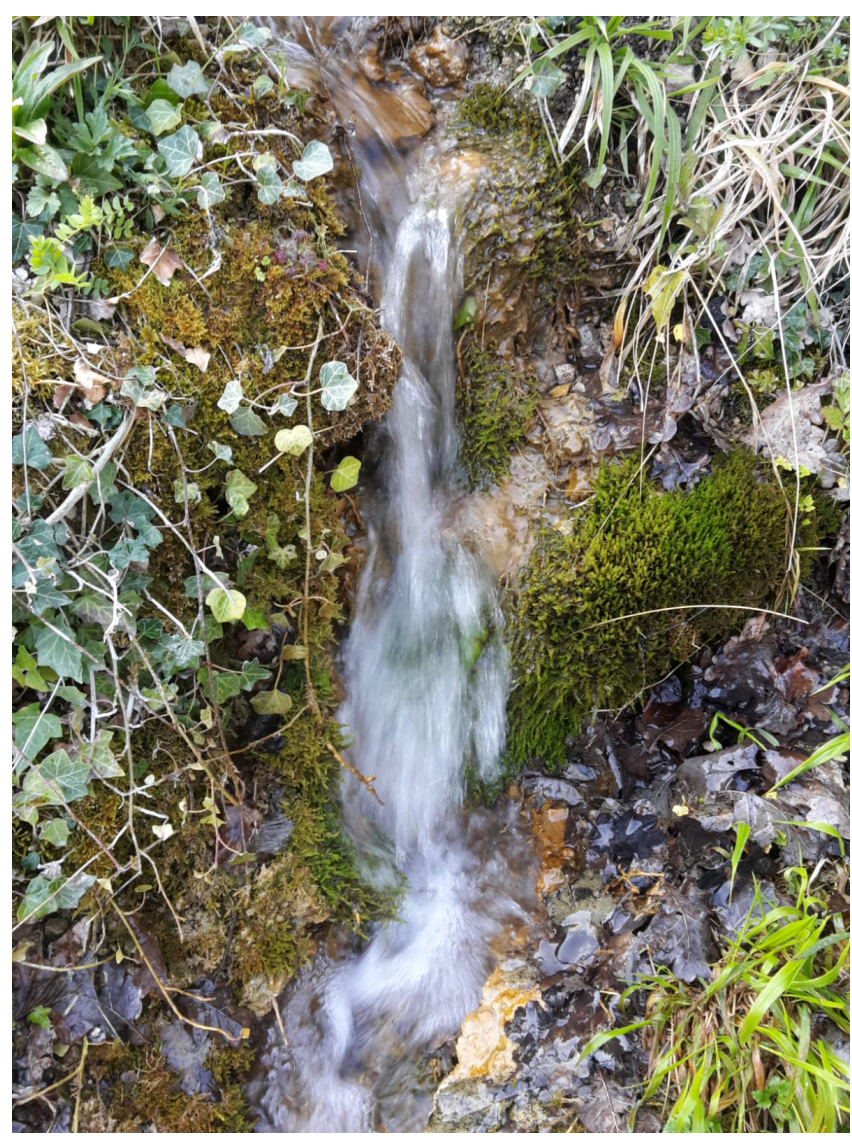

Figure 6. (Ambre) A future dry abandoned land with bindweed. This figure is distributed under the Creative Commons licence Attribution-NonCommercial-NoDerivs (CC BY-NC-ND).

negotiations on climate change mitigation, Juliette thinks that we will destroy the basis of life.

Louise and Jules are in anguish for the world, for their grandchildren and for the future, though not for themselves because they do their best. Over the past 4 to 5 years, their crop production has decreased by a third, especially hay for livestock, because of water shortage. The decrease in plant production has also affected animals like fish, insects and birds, which are attacking plants in unusual ways. For example, foxes now eat beetroots. These changes produce for the couple "more than worry, more than anxiety".

Ambre feels sad, disgusted, gloomy and demoralised. In imagining a probable future, she saw no forest near the little stream (Fig. 6) anymore; the abandoned ground will be covered by a $1 \mathrm{~m}$ high dense bindweed-type vegetation: "apart from these grasses, no life was left, only dead ground." She could not breathe properly when imagining the probable future. These feelings inspire her to do "nothing" or to "do [her] best to keep the place as it is", because she does not know if she can do something that will change the probable future she envisions where huge, destructive and imminent climatic changes will have made human activities cease; this future seems to her irreversible. Reflecting on her emotions, she adds: "the desired future can be invented any way you want. But the probable future, we can't invent it any way we want, because it's probable. ... So, it still scares me that I saw that."

All respondents see a probable future of the photographed waterscapes to be drier, bushier and rockier. They express feeling sad, anxious and fearful when considering probable futures and environmental changes. The responses show that participants think of futures in metaphorical associations between waterscapes, distant in time and space.

\subsection{Desired futures - plural visions, emotions and actions}

After discussing probable futures, the participants express their desired future for the waterscapes. They imagine sitting on a bench in 2222 and discussing pathways to reach the desired futures with someone who knew the history of this place from the year 2019 to 2222 .

The waterscape Gabriel hopes for has fruit trees and vegetable crops around it and grazing cattle and beautiful forests in the hills. Fruit trees imply more people working and living there. This means life and noise, like the sound of the chainsaw - which we actually hear during the discussion and children playing, "not a dying village like in the south of France" where he has spent holidays. By describing people and life, his desired future opposes his vision of probable wars and social deprivation. As before, he associates the south of France and the Jura not only with visual and ecological characteristics of landscapes but also with sociodemographic realms.

Gabriel describes "a great pleasure to live, to get up in the morning and do the work [he loves]" in a world where "the race for money, this race to make things bigger," would be over. In contrast, Juliette's visions of a desired future produce a melancholic sadness in her "because we are mortals". She is sad that she will not live long enough to see the many projects with low-impact electric power plants and collective organic farming that she envisions will have mushroomed all around the waterscape, one whose riverbank will be carved into a canyon.

Regarding pathways to his desired future, Gabriel foresees that the water quality would improve as a result of better awareness and avoidance of damaging practices. Responding to the probable risks of drought and biodiversity loss, Gabriel envisions that "we will have had to stop laying concrete" and pursue "a living agriculture, not a monoculture." To avoid the probable conflicts, Gabriel proposes to "take responsibility for ourselves a bit" (s'assumer un peu). In opposition to "delegate everything, be opportunistic and grab what [we] like", we should raise "our awareness that all regions are liveable, our modesty to live with what we have, and our recognition of being well where we are". Moreover, we should "put in extra taxes or take the tyres off the aeroplanes" to diminish 
traffic and "bring a vision of this landscape without a motorway".

Rose feels uplifted by the idea "that we can overcome ourselves, change, evolve, move forward". She expresses her goals as degrowth in opposition to "mishandling land to produce more and more", diversity in opposition to monoculture, rationalised globality in opposition to being tributaries of trade agreements, and "a Switzerland of organic gardens". Knowledge, information and education over generations will support reinventing agriculture and preserving landscapes. She also wants to raise awareness of biodiversity by word of mouth, "speaking objectively, encouraging people to consume locally, to eat all-natural products, to think about transport".

Jules describes a desired future with one-third of the human and animal population surviving after 2050. "It's the apocalypse", his wife whispers, and he admits, "some kind of apocalypse" while describing a post-apocalyptic awakening: maybe the climate will change; maybe the ice cap will form again. Automatically, population decrease will relieve the planet for the remaining humans and animals. Today's structures of ownership, empires, wealth or money will automatically disappear. "The new ones will start again in a new world", he laughs, considering himself a dreamer. "Either the Earth will eliminate us and then start again from almost nothing, with few people left", or voluntarily "the people, the world, take the bull by the horns and turn in the direction of true values". He foresees that people will give priority to minimalist needs: eating, drinking, sleeping, perhaps hunting - "activities that we find minimalist in some tribes where the essential thing will be to live in the simplest way, ... forgetting all materialism". As sustainable pathways, Jules recommends a return to the land, a governmental land redistribution, teaching young people to be in charge and producing food ourselves without having to pay for it. "Let people start producing their food again and stop relying on too few people to feed too many."

Louise sees that in 2222, "we are all eco-friendly organic [producers]. Stop trashing our grounds and then our lives. Stop these big machines, these monsters beating oats or wheat. No more of those agrochemical companies that have created needs." Jules adds, "Useless needs. They lied to us, stole, cheated. Today we are robbed. It's grand larceny, robbery in organised gangs." He feels enslaved by big companies. Louise specifies that today, "if the government did not support us, we [farmers] would be slaves". She contrasts this with a desired future where "if a smaller area were needed to do it [farm] properly, other families could be supported on the remaining plots."

Léo envisions more "radical" futures that would shift access to natural resources from tradeable rights to equal rights. His "utopian" vision is inspired by "the communist system" which sets different values: "to have food, a social life, hobbies, leisure time". He envisions that resources such as oil, water, electricity or plastic will become controlled at some point: "it may come from regulation or, if not, nature will do it for us instead". According to available water, "each inhabitant will strictly be entitled to so many litres", and for energy, "so many kilowatts". Hybridising his communist utopia, he adds, "on the other hand, if you want to produce your green energy on the side, I think it's possible: you can do it yourself. And water as well - if you want to collect water from roofs and wash your car every day, it is up to you, because you haven't used a resource that everybody needs."

Moreover, Ambre envisions that in 2222 we will have developed special sensitivities to immaterial beings such as spirits or souls that extend to the land: "We need to stop the bleeding. Stop cutting down forests. We will all be responsible for a little patch of land, not necessarily as landowners." Driven by a collective awareness, each person will "take her/his little piece of land and do her/his best, let it live, talk to it, like a living being - because it $i s$ a living being - feed it and take care of it".

The envisioned desired futures are diverse due to the diffractive process of speculation, making many possibles diverging from the probable future, although they follow similar directions.

\section{Discussing realism in dissociation from the frontier spirit}

Adam and Groves (2007) suggest that the fragmentation of industrial societies has been dismantling pre-existing "social chains of obligation, care and responsibility" towards future generations by setting new institutions (economy, politics and law) which enable acting with a "frontier spirit". This inter-generational "structural irresponsibility" (Adam and Groves, 2007:42, 203) relies on the fact that responsibility depends on knowledge, and knowledge of the future is uncertain. Therefore, short-term actions take on a frontier spirit in "social practices of future making which demarcate, colonise and transform unutilised territories (wilderness) into economically profitable resources" (Adam and Groves, 2007:196). Hence, actions are "disconnected from a sense of obligation and responsibility extending into the future as far as the effects of decisions, actions and inactions are going to reach" (Adam and Groves, 2007:117-118). Subsequently, the uncertain impacts and costs of detrimental actions are externalised to other nations and future generations more fragile to global change and biodiversity loss.

Some participants criticise structural irresponsibility embedded in past dependency on the frontier spirit. For instance, Jules mentions how past actions influence our ability to shape futures referring to the shift of European overseas frontiers: "Christopher Columbus wanted to discover America; we won't stop him". Our future inability to intervene on past actions can be interpreted as a statement that past dependency impacts our capabilities to deal with the consequent globalisation that Columbus initiated. In analogy to the 
7-year cycles of moles, Jules considers that we are closing a half-millennium cycle of human expansion. This long-term cycle is the result of "the economy and globalisation", driven by what Louise and Jules call "curiosity" about everything: travel, imported goods and so on.

Concerning structural irresponsibility, participants also question the responsibility of science, politics and the economy. Louise states that "the men who created these [damaging technologies], the scientists, are very nice people, but they ate our air and destroyed our environment". Jules expresses how politicians also enact the frontier spirit: "our leaders are insistent on forcing us to produce as much as possible". Nonetheless, he ponders whether changes will come from politics, even though politicians fear economic consequences. Juliette states that the emergency of the situation is not taken seriously in political decisions; we would need to change the entire system: "System change, not climate change". According to her, in the capitalist system, many human needs have been monetised and diverted to material goods. For example, "we do not need fancy clothes; we need to be seen, loved and recognised by others". Léo considers that "someday, we will not be able to live any longer with a system where food is part of the economy. If the economy manages food, it goes to extremes that are unsustainable."

Participants also raise concerns about global changes and biodiversity loss in regions where the frontier spirit prevails, regions sometimes as far from the Jura as the Amazon. Jules is appalled that indigenous peoples in Brazil are "increasingly cornered in reserves .... We cut all around them, kicking them out of their territory to log, mine, exploit the riches of the Earth. We need to stop human and natural resource exploitation." Gabriel criticises the responsibility of importers too: "the Amazon is still being deforested to produce cereals to feed livestock here [in Europe]. We all cry like fools when seeing this forest cut down; ... meanwhile, we participate in it." Importing feed grains from far away causes deprivation there, "so, we should react": "If now we really put the true value on the gasoline and fuel to get food here at the real price, ... physical protection may not be needed ..., when we have it economically". Rejecting an interpretation of his desired pathway as "ecological protectionism", Gabriel prefers the term "realism" in opposition to the socioecological "nonsense" (aberration) of the current economy. He has regularly been told that "you can't do that [environmentally friendly project] because economically it does not make profit." Confronted with the inability to do everything well for both the environment and his business, Gabriel experiences both self-blaming behaviours and disappointment with the economic system.

Research participants often problematise the incoherence between ecological and economical imperatives and criticise systemic or structural irresponsibility. Moreover, they raise concerns as if they would like to dissociate their desired futures from the frontier spirit that is leading ecosystem depletion and economic profit in the Jura and in remote re- gions such as the proverbial Amazon. Participants' concerns over South America might emerge from the EU-Mercosur free trade agreements raising "valid concerns" on "greenhouse gas emissions, deforestation [and] biodiversity" (Francois et al., 2020:12) or from the EFTA-Mercosur free trade agreement. The last could probably result in $901 \mathrm{~km}^{2}$ of additional deforested land by 2040 as well as in an additional USD 290 million of chemical product export from Switzerland to Mercosur each year (Francois et al., 2020:34). Thus, the references to distant regions and times by participants bring another complex form of metaphorical association: dissociation or definition of the desired waterscape by contrast.

\section{Discussing futurity through visuality and emotionality}

Following material-semiotic approaches (Haraway, 1988), we analyse metaphors which juxtapose the material and the semiotic "to imagine "complexity" (Schlottmann and Miggelbrink, 2009:3). As performances and metaphors produce cultural consensus over the future (Appadurai, 2013:184), we could begin "to alter our relationship with the future" by changing "the concepts and metaphors through which we approach it" (Adam and Groves, 2007:122).

Participants sometimes describe their futures as appearing like different media genres. For instance, Ambre expresses that her desired future mimics comics and cartoons depicting a desired world where everyone is nice and happy; in contrast, her probable future looks "like in the science-fiction movies": grey. Colours are also used as metonymic visual metaphors. Envisioning variegated futures, Ambre describes the probable Earth as "not really green, more brownish, not very colourful". The desired Earth, however, is different: "from a distance I could see it very blue, very colourful compared to the other one which was dull and dark". At the waterscape level, it looks "more or less the same as the picture with more colours". The perceptions of different colours are associated with imagined diverging consequences of climate warming and air pollution which will have impacted daylight and vegetation type. They also connote emotional states related to dullness and darkness.

Though speculation is etymologically derived from the Latin term for contemplation and observation (speculationem) (Åsberg et al., 2015:152), sensory experiences such as touch and smell also influence futurity beyond the visual. Rose sees "how the Earth behaves because [she] lives in it". "[Rose's] feet are [rooted] in the soil", she says. She sees the evolution of the forest: "trees suffered, and, cracked, the bark burst, and then the trees died" because the summer of 2019 was too hot and dry. "Water diminishes in springs", and she wonders how to water eighty cows. She feels "an emotion of attachment, of being linked to nature ..., an emotion that is palpable", that brings tears to her eyes, that touches her. Her observations are sensory-affective, sharing trans- 
corporal bonds to the Earth, forests, land, water and cattle. Her relative and morally binding speculation emerges from these bonds.

Emotions - as materially embodied - also influence and are influenced by futurity. According to our results, projections into probable futures create fear, anxiety and sadness. These emotions incite either a fighting response by denouncing natural resources and human exploitations or, for Ambre, a feeling of paralysis when confronted by the irreversibility of global change. Some discourses sound quite cynical on the first impression: Louise and Jules "have seen too much ... and can no longer believe in humankind", because "humans have no more wisdom, respect, nor belief in anything: the essential values to remain humble". Yet, Adam and Groves (2007) would interpret that these are values on which to build social chains of care and obligation towards future generations. Likewise, Louise stresses the emergency of enhancing response-ability now which we interpret as a criticism of the active or passive inertia characterising both "technofix" and "game-over" discourses: "Will our grandchildren be able to do something? ... Surely not more than we can do." These results balance hypotheses from Cook and Balayannis (2015) and Haraway (2016) in the sense that, though participants fear global changes in biodiversity, most participants do not express game-over attitudes or technofix solutions: they oppose probable drought and biodiversity loss by advocating stopping what is creating them. This corroborates Lefebvre's description of a revolutionarily romantic attitude (2011) affirming that the value of the future and its realisation can only result from a period of lucidly supported waiting and tension in a quiet and permanent challenge to the existing: opposing justice with injustice, truth with illusion and authenticity with lies.

In contrast, all participants, with the exception of Juliette, experience positive feelings when telling their desired futures. Meanwhile, they express a greater commitment to act resourcefully towards creating desired waterscapes, especially when they are conscious of the dialectic of the possible-impossible. They seem empowered and propose transformative changes for acting towards their visions. For instance, Gabriel declares that he would "sign right now" for having the same water quantity available in 200 years, meaning that he would do everything he could to reach this goal of taking response-ability for waterscapes over 200 years. Juliette, on the other hand, feels sad not to be able to see her desired future full of collective farming projects. She reflects that she "could just extrapolate [her vision of her own life and her collective farming project] to the whole society, though it is not a strategy, unfortunately". Her reflection illustrates how the capacity to aspire (Appadurai, 2013), to transform probable into desired futures, is a meta-capacity which gives meaning, substance and sustainability to a particular group, in her case, collective farming projects.

The speculative construction of a desired future conceptually reorganises semantic spaces, links material and social relations, and expands an (emic) vision of our present social reality to an epic horizon, as described for science fiction (Hellstrand, 2017). For instance, the imaginative ways of seeing the two planet Earths from outer space intertwine and contrast with imaginaries, attached to technological views of satellite imageries. Jasanoff (2001) emphasises that images of the Earth from Apollo 17 play a key role in global environmental consciousness, resonating "with the themes of finiteness and fragility, and of human dependence on the biosphere". Likewise, during her imaginative landing on the desired planet in the future, Rose sees more light pollution in the Global South and less in the Global North. She extrapolates this image from the recent decision by several municipalities in the Jura to switch off street lights at night. On the other hand, she voices a vision depicting a more equal development of public infrastructures worldwide. In this sense, the extra-terrestrial gaze seems to be an exhilarating vision, empowering participants in their own world views to raise global concerns.

\section{Conclusion - landings and worldings}

As the saying goes in the Jura dialect, "Le pus bé dichoué chu l'avé ne pésse pe lai soi" ("the most beautiful talk about water doesn't quench your thirst") (Chapuis, 2018). Conversely, narratives can "populate our worlds and imaginations in a different way" (Stengers, 2011:371), as it "matters what stories make worlds, what worlds make stories" (Haraway, 2016:12). In our research, the imaginative time-space journey gave confidence for landing on the two planets. Subsequently, our narratives may perform and transform human interactions, making the most probable world or the most desired world. Hence, voicing plural imagined futures of farmers - as a particular group which, according to Adam and Groves (2007), has less institutional legitimacy to transform present imaginaries of futures than scientists, politicians or economists - is an act of resistance to the probable degradation of waterscapes that the farmers are facing.

To narrow down our analysis, we interpret how metaphors in probable and desired futures expressed by participants associate or dissociate distant places in space and times through teleo-affectivity (Stephan, 2018:155, referring to Schatzki et al., 2001), i.e. orientations towards finality: what matters to us, what we care about, as a component of sites linking waterscapes to larger contexts at various scales. Our results show two commonalities among narratives. Firstly, the associations between the Jura in the probable future and southern regions nowadays can be analysed as regional discursive formations assembling its futurity. Secondly, when dealing with global concerns, waterscapes seem bonded to distant places where the frontier spirit leads to biodiversity destruction and economic profits, urging participants to act against the probable destruction of ecosystems. The desired future of the photographed waterscape is defined in con- 
trast to these places and in dissociation from their probable ecological degradation. We interpret these discourses as engaged expressions of international solidarity and multispecies response-ability informed by conscious world views of globalisation processes such as the import of Brazilian fodder for European livestock. The research participants talk about various non-human beings (i.e. cows, foxes, moles, trees, Earth, ponds, rivers, forests, soil, spirits, etc.) interacting in material-semiotic relations (sensorially experienced and metaphorically meaningful). Their multispecies worldings are promoting practices of care and response.

In reaction to the probable future focusing on concerns over ecosystem depletion and drought, speculative photoresponse fabulation also develops more engaged geographies of desired futures. As the figure of the diplomat crafting peace (Stengers, 2018), Gabriel's desired "realism" opposes his vision of a probable "fight over resources", and Léo's desired revolution opposes probable "civil wars over food and water". Conscious of the dialectic of the possible-impossible (Lefebvre, 1957), participants expose possible visions that may appear improbable in their implementation in the current economic system characterised by the labour division between too few farmers and too many consumers or between problematic food production in remote regions and its import into European markets. In this way, the research participants (re-)claim alternative futures by more or less explicitly articulating ideological projects.

Participants' revolutionarily romantic visions could potentially compete at this quasi-ideological level between a realism opposing the nonsense of an economic system; a postapocalyptical, minimalist tribal system; a communist quota system on shared resources; degrowth to promote diversity with "a rationalised globality" in opposition to being tributaries of trade agreements; rhizomatic, solidary farming communities; a world of spirits; or an eco-friendly, zeropesticide world. The plurality of told futures reflects different understandings and interpretations of nature. Moreover, the diffractive nature of speculation opens vast areas of what research participants consider important, what matters to them and what they care about in waterscapes. Still, our approach narrows down pragmatically the possible actions to the ones that participants think would take care of waterscapes.

At the material level, participants envision practices which can coevolve in symbiosis in the "co-weaving of evolution" (Stengers, 2018:91) and inspire participants and others to act on their own or collectively towards plural desired visions. In other words, all the formulated desired pathways go pragmatically towards response-ability and in the opposite direction of a frontier spirit by raising awareness (conscience) over biodiversity loss, limiting transport-induced pollution, developing food systems decoupled from economic imperatives, facilitating land access linked to caring and prioritising the fulfilment of essential needs (among which to eat, sleep and have a social life, as well as to be seen, loved and recognised by others, were mentioned). Participants risk telling their situated and relative truth because they feel bound by the urgent situation of probable ecological destruction. This situation is made perceptible only by the way in which they feel bound - embedded in interconnected and interdependent webs of lives, nurtured by social memories, and concerned by the processuality of our actions into the future - in an attempt to attain what Adam and Groves (2007:93-97) would call "futurity redeemed".

Speculative photo-response fabulation creates new possibilities for politics (Braun, 2015). In order to overpass insufficient interactions between researchers, policy-makers, and stakeholders, participatory-scenario facilitators incorporate local views in order to include local guidance and support for decision-making (Kabaya et al., 2018, referring to IPBES, 2016, and Oteros-Rozas et al., 2015). In this respect, research participants' formulated regional (and global) discursive formations on possible-impossible futures of waterscapes could play an important role in socio-ecological transformation scenarios and solution-oriented participatory change management processes (see Pahl-Wostl et al., 2020). To transform economies and everyday practices, we acknowledge that "attempts at behaviour change, regulations, and global agreements confront the realities of material and socialpolitical infrastructures that support the status quo" (Nightingale et al., 2020:343). Hence, being conscious of the necessary possible changes even if they appear improbable in their application is a key cognitive capacity to transform futures, i.e. "to unravelling the capacities to reduce the resilience of the undesired, status quo system as well as nurturing and navigating the emergence of new, desired systems" (HerrfahrdtPähle et al., 2020:1).

Code availability. The codes are not publicly available.

Data availability. Participants did not grant permissions for further analysis of our discussions by other researchers.

Author contributions. RW and NB designed the research. The research participants made the pictures and interpreted them. RW gave the guidelines and led and transcribed the discussions. NB and RW wrote the article jointly.

Competing interests. The authors declare that they have no conflict of interest.

Acknowledgements. We thank all research participants, whose names are anonymised, for their time, trust and commitment, as well as Sara Landolt, Sarah Becker, Jessica Huber and Jennifer Bartmess for their feedback. This study was supported by the University Research Priority Programme Global Change and Biodiversity (URPP GCB) of the University of Zurich. 
Financial support. This research has been supported by the University Research Priority Programme Global Change and Biodiversity (URPP GCB) of the University of Zurich.

Review statement. This paper was edited by Christiane Stephan and reviewed by two anonymous referees.

\section{References}

Adam, B. and Groves, C.: Future Matters: Action, Knowledge, Ethics, Brill, Leiden and Boston, 2007.

Alam, A., McGregor, A., and Houston, D.: Photoresponse: Approaching participatory photography as a more-than-human research method, Area, 50, 256-265, https://doi.org/10.1111/area.12368, 2018.

Appadurai, A.: The Future as Cultural Fact: Essays on the Gobal Condition, Verso, London, 2013.

Åsberg, C., Thiele, K., and van der Tuin, I.: Speculative Before the Turn Reintroducing Feminist Materialist Performativity, Cult. Stud. Rev., 21, 145-172, https://doi.org/10.5130/csr.v21i2.4324, 2015

Braun, B.: Futures: Imagining Socioecological Transformation - An Introduction, Ann. Assoc. Am. Geogr., 105, 239-243, https://doi.org/10.1080/00045608.2014.1000893, 2015.

Chapuis, B.: Notre Coénat: Histoires patoises, Société jurassienne démulation, Delémont, 2018.

Cook, B. and Balayannis, A.: Co-Producing (a Fearful) Anthropocene, Geogr. Res., 53, 270-279, https://doi.org/10.1111/17455871.12126, 2015

Debaise, D. and Stengers, I.: The Insistence of Possibles: Towards a Speculative Pragmatism, Parse J., 7, 12-19, 2017.

Derickson, K. D. and MacKinnon, D.: Toward an Interim Politics of Resourcefulness for the Anthropocene, Ann. Assoc. Am. Geogr., 105, 304-312, https://doi.org/10.1080/00045608.2014.1001002, 2015.

Francois, J., Häberli, C., Manchin, M., Polanco, R., RojasRomagosa, H., and Tomberger, P.: Assessment of the potential environmental impacts and risks in Switzerland and the MERCOSUR States resulting from a Free Trade Agreement (FTA) between the EFTA States and MERCOSUR, SECO, Bern, 2020.

Haraway, D.: Situated Knowledges: The Science Question in Feminism and the Privilege of Partial Perspective, Fem. Stud., 14, 575-599, https://doi.org/10.2307/3178066, 1988.

Haraway, D. J.: Staying with the Trouble - Making Kin in the Chthulucene, Duke University Press, Durham, London, 2016.

Hefti, D., Hofmann, D., Marendaz, E., and Ofen, O.: Plan d'action national en faveur du Doubs, Démarche générale, available at: https://www.bafu.admin.ch/dam/bafu/fr/ dokumente/wasser/ud-umwelt-diverses/plan_d_action_ nationalenfaveurdudoubsdemarchegenerale.pdf (last access: 31 March 2021), 2015.

Hellstrand, I.: From Metaphor to Metamorph? On Science Fiction and the Ethics of Transformative Encounters, NORA - Nord. J. Fem. Gend. Res., 25, 19-31, https://doi.org/10.1080/08038740.2017.1309456, 2017.

Herrfahrdt-Pähle, E., Schlüter, M., Olsson, P., Folke, C., Gelcich, S., and Pahl-Wostl, C.: Sustainability transfor- mations: socio-political shocks as opportunities for governance transitions, Global Environ. Chang., 63, 1-22, https://doi.org/10.1016/j.gloenvcha.2020.102097, 2020.

Hoffmann, S., Hunkeler, D., and Maurer, M.: Nachhaltige Wasserversorgung und Abwasserentsorgung in der Schweiz: Herausforderungen und Handlungsoptionen. Thematische Synthese $3 \mathrm{im}$ Rahmen des Nationalen Forschungsprogramms NFP 61 "Nachhaltige Wassernutzung", Schweizerischer Nationalfonds zur Förderung der wissenschaftlichen Forschung, Bern, 2014.

IPBES: Summary for policymakers of the methodological assessment of scenarios and models of biodiversity and ecosystem services of the Intergovernmental Science-Policy Platform on Biodiversity and Ecosystem Services, Secretariat of the Intergovernmental Science-Policy Platform on Biodiversity and Ecosystem Services, Bonn, Germany, 2016.

Jasanoff, S.: Image and Imagination: The Formation of Global Environmental Consciousness, in: Changing the atmosphere: expert knowledge and environmental governance, edited by: Miller, C. and Edwards, P., MIT Press, Cambridge, 309-37, 2001.

Kabaya, K., Hashimoto, S., Fukuyo, N., Uetake, T., and Takeuchi, K.: Investigating future ecosystem services through participatory scenario building and spatial ecological-economic modelling, Sustain. Sci., 14, 1-12, https://doi.org/10.1007/s11625018-0590-1, 2018.

Lefebvre, H.: Vers un romantisme révolutionnaire, La Nouvelle Revue Française, 58, 644-672, 1957.

Nightingale, A. J., Eriksen, S., Taylor, M., Forsyth, T., Pelling, M., Newsham, A., Boyd, E., Brown, K., Harvey, B., Jones, L., Kerr, R. B., Mehta, L., Naess, L. O., Scoones, I., Tanner, T., Whitfield, S., Joslyn, A., Eriksen, S., Taylor, M., Forsyth, T., Pelling, M., Newsham, A., Boyd, E., Brown, K., Harvey, B., Jones, L., Kerr, R. B., Mehta, L., Naess, L. O., Ockwell, D., Scoones, I., and Tanner, T.: Beyond Technical Fixes: climate solutions and the great derangement, Clim. Dev., 12, 343-352, https://doi.org/10.1080/17565529.2019.1624495, 2020.

Oteros-Rozas, E., Martín-López, B., Daw, T., Bohensky, E. L., Butler, J., Hill, R., Martin-Ortega, J., Quinlan, A., Ravera, F., RuizMallén, I., Thyresson, M., Mistry, J., Palomo, I., Peterson, G. D., Plieninger, T., Waylen, K. A., Beach, D., Bohnet, I. C., Hamann, M., Hanspach, J., Hubacek, K., Lavorel, S., and Vilardy, S.: Participatory scenario planning in place-based social-ecological research: insights and experiences from 23 case studies, Ecol. Soc., 20, 4, https://doi.org/10.5751/ES-07985-200432, 2015.

Pahl-Wostl, C., Knieper, C., Lukat, E., Meergans, F., Schoderer, M., Schütze, N., Schweigatz, D., Dombrowsky, I., Lenschow, A., Stein, U., Thiel, A., Tröltzsch, J., and Vidaurre, R.: Enhancing the capacity of water governance to deal with complex management challenges: A framework of analysis, Environ. Sci. Policy, 107, 23-35, https://doi.org/10.1016/j.envsci.2020.02.011, 2020.

Pihet, V., Debaise, D., Solhdju, K., and Terranova, F.: Speculative Narration: A Conversation with Valérie Pihet, Didier Debaise, Katrin Solhdju and Fabrizio Terranova, Parse J., 7, 64-77, 2017.

Pink, S. and Salazar, J. F.: Anthropologies and Futures: Researching Emerging and Uncertain Worlds, edited by: Salazar, J. F., Pink, S., Irving, A., and Sjoberg, J., Bloomsbury Publishing PLC, London and New York, 2017. 
Schatzki, T. R., Cetina, K. K., and von Savigny, E. (Eds.): The Practice Turn in Contemporary Theory, Routledge, London, New York, 2001.

Schlottmann, A. and Miggelbrink, J.: Visual geographies - An editorial, Soc. Geogr., 4, 1-11, https://doi.org/10.5194/sg-4-1-2009, 2009.

Schlottmann, A. and Miggelbrink, J.: Visuelle Geographien: Zur Produktion, Aneignung und Vermittlung von RaumBildern, Vol. 2., transcript Verlag, Bielefeld, 2015.

Stengers, I.: Wondering about materialism, in: The speculative turn: Continental materialism and realism, edited by: Bryant, L., Srnicek, N., and Harman, G., re.press, Melbourne, 368-380, 2011.

Stengers, I.: The challenge of ontological politics, in: A World of Many Worlds, edited by: de la Cadena, M. and Blaser, M., Duke University Press, Durham, 83-111, 2018.
Stephan, C.: Social practices of flood (risk) management - a visual geographic approach to the analysis of social practices in an empirical case in Chiapas, Mexico, Erdkunde, 72, 151-168, https://doi.org/10.3112/erdkunde.2018.02.06, 2018.

Taylor, C.: Modern social imaginaries, Duke University Press, Durham, NC, 2004.

Thrift, N.: Non-Representational Theory: Space, Politics, Affect, Routledge, Abingdon, New York, 2008.

Wagner, J. R.: Water and the Commons Imaginary, Curr. Anthropol., 53, 617-641, https://doi.org/10.1086/667622, 2012.

Wilkie, A., Savransky, M., and Rosengarten, M.: Speculative Research. The Lure of possible futures, Routledge, Oxon, New York, 2017. 